\title{
Guillain-Barré syndrome following heart transplantation complicated by myocardial infarction following treatment with IVIg
}

\author{
Joshua Newman*1, Andrew Chen ${ }^{1}$, Saud Rana ${ }^{1}$, Max Liebo ${ }^{2}$ \\ ${ }^{1}$ Department of Internal Medicine, Loyola University Medical Center, Maywood, United States \\ ${ }^{2}$ Center for Heart and Vascular Medicine, Loyola University Medical Center, Maywood, United States
}

Received: May 13, 2017

DOI: $10.5430 /$ crim.v4n3p39
Accepted: June 28, 2017

Online Published: July 16, 2017

\begin{abstract}
Guillain-Barré syndrome (GBS) is rare autoimmune polyneuropathy that is infrequently seen in the post-transplant population, presumably due to the presence of immunosuppression. When it does occur in this setting, Cytomegalovirus (CMV) infection is a common inciting factor. Treatment modalities for GBS include intravenous immunoglobulin (IVIg) or plasmapheresis. Rarely, IVIg infusion has been associated with myocardial infarction. We describe a case of a patient status post heart transplantation who presented with GBS shortly after developing CMV viremia. When treatment with IVIg was initiated, our patient developed myocardial infarction with acute cardiac biomarker elevation, acute systolic dysfunction, and cardiogenic shock requiring inotropic and vasopressor support. Coronary angiography demonstrated no significant coronary artery disease. The patient's cardiac function recovered, as did the GBS following initiation of plasmapheresis. We review prior cases of GBS in transplant patients as well as IVIg associated myocardial infarction.
\end{abstract}

Key Words: Guillain-Barré syndrome, Heart transplant, Hyperviscosity syndrome, Cardiogenic shock, Cytomegalovirus, Intravenous immunoglobulin

\section{INTRODUCTION}

Guillain-Barré syndrome (GBS) is a progressive polyneuropathy that classically presents as an ascending paralysis with or without sensory symptoms several weeks following an infection. Other possible clinical manifestations of this syndrome include respiratory failure, autonomic dysfunction, and rarely acute coronary syndromes and heart failure. ${ }^{[1,2]}$ The most common inciting event in the general population is an infection with Campylobacter jejuni, found in $25 \%$ $50 \%$ of adult patients; however, multiple other infectious and noninfectious etiologies have been described. ${ }^{[1]}$
Current understanding of the pathophysiology of this syndrome implicates molecular mimicry between microbial glycans and glycans present on the surface of nerve gangliosides. Subsequently, cross-reactive antibodies lead to the destruction of the myelin sheath and consequent morbidity. While the incidence of GBS is estimated to be 0.8-1.9 cases per 100,000 people per year in the general population, it is notably less common in the transplant population. ${ }^{[1]}$ As this syndrome is driven by an immune mediated mechanism, it has been postulated that this reduced incidence in the transplant population is due to a protective effect of immunosuppres-

\footnotetext{
* Correspondence: Joshua Newman; Email: Joshua.Newman@lumc.edu; Address: Department of Internal Medicine, Loyola University Medical Center, 2160 S 1st Avenue, Building 102, Room 7609, Maywood IL 60153, United States.
} 
sion. ${ }^{[3]}$ Intravenous immunoglobulin (IVIg) administration and plasmapheresis are well established treatment modalities for GBS. IVIg is considered a safe medication with the majority of its side effects being mild; however, it has rarely been associated with development of hyperviscosity syndrome, and there have been case reports of thrombosis and myocardial infarction in patients receiving treatment with IVIg. ${ }^{[4]}$

Herein we describe the case of a patient status post heart transplantation that developed GBS likely induced by CMV viremia whose clinical course was complicated by myocardial infarction, respiratory failure, and cardiogenic shock immediately following treatment with IVIg.

\section{CASE PResentation}

Our patient is a 50-year-old caucasian male with a past medical history significant for non-ischemic cardiomyopathy status post orthotopic heart transplant in 2014 (CMV donor positive, recipient negative), a remote history of non-Hodgkin's lymphoma treated with chemotherapy and radiation, and Crohn's disease complicated by ischemic colitis who was admitted to the hospital in March 2016 due to new-onset paresthesias. The patient's post-transplant course had been complicated by (1) multiple episodes of ISHLT Grade 2R acute cellular rejection treated with pulse dose steroids, most recently one week prior to presentation; (2) hospitalization for diarrhea approximately 3 months prior to presentation with extensive gastrointestinal evaluation unrevealing at which time prophylactic valganciclovir, which he had been taking since his transplant 13 months prior, was discontinued due to repeated negative serum $\mathrm{CMV}$ polymerase chain reaction (PCR); and (3) readmission for recurrent diarrhea associated with dehydration and acute kidney injury one month prior to presentation at which time stool PCR returned positive for norovirus and serum studies revealed low grade CMV viremia (145 international units [IU] per ml). The patient's diarrhea and renal function improved with hydration, and valganciclovir was restarted; however, his CMV viremia continued to rise as an outpatient, peaking at $1,110 \mathrm{IU} / \mathrm{ml}$ two weeks prior to being admitted for paresthesias.

On presentation, he reported numbness and tingling in his fingers and toes of four days duration. Initial exam was notable for diminished reflexes but normal strength. The following day, he developed motor weakness characterized by $3 / 5$ muscle strength in the lower extremities and $4 / 5$ muscle strength in the upper extremities, as well as areflexia. Results of cerebrospinal fluid analysis are shown in Table 1. Electromyogram revealed reduced sensory nerve action potential
(SNAP) amplitude and nerve conduction velocity (NCV) in the right sural nerve. Both SNAP and NCV were absent in the left sural nerve. Peroneal nerve compound muscle action potential (CMAP) amplitudes were reduced with temporal dispersion. Similar abnormalities were noted in the right tibial motor nerve. In the right ulnar and median nerve, there was also reduced median CMAP amplitude and slowed NCV. These findings were consistent with GBS and he was thus started on IVIg. At the time, his negative inspiratory force (NIF) was -50 centimeters of water $\left(\mathrm{cm} \mathrm{H}_{2} \mathrm{O}\right)$.

Table 1. Results of cerebrospinal fluid analysis

\begin{tabular}{ll}
\hline Item & Result \\
\hline Clarity & Clear \\
Color & Colorless \\
WBC & 1 \\
RBC & 0 \\
Lymphocytes & $67 \%$ \\
Monocytes & $22 \%$ \\
Macrophages & $11 \%$ \\
Glucose & 96 \\
Protein & 34 \\
Culture & No growth \\
CMV PCR & Not detected \\
EBV PCR & Not detected \\
VZV PCR & Not detected \\
HSV 1 \& 2 DNA PCR & Not detected \\
West Nile Virus PCR & Not detected \\
\hline
\end{tabular}

Several hours after the first dose of IVIg was initiated, he complained of worsening shortness of breath. Chest x-ray showed pulmonary edema and his NIF had worsened to $-20 \mathrm{~cm} \mathrm{H}_{2} \mathrm{O}$. The patient was electively intubated given concern for respiratory failure secondary to GBS. Laboratory evaluation at this time revealed a troponin I of $34.99 \mathrm{~g} / \mathrm{ml}$. Electrocardiogram showed inferolateral ST depressions with ST elevation in aVR (see Figure 1). Echocardiogram showed a newly reduced left ventricular ejection fraction (LVEF) of $40 \%$ with global hypokinesis and some regional variation. Emergent coronary angiography showed no obstructive coronary lesions (see Figure 2). Right heart catheterization was notable for a reduced cardiac index of $1.88 \mathrm{~L} / \mathrm{min} / \mathrm{m}^{2}$, elevated systemic vascular resistance of 1,922 dynes $\times \mathrm{s} / \mathrm{cm}^{5}$, and a mildly elevated pulmonary capillary wedge pressure of $16 \mathrm{mmHg}$. The patient became hypotensive and was started on dobutamine and norepinephrine. Over the course of the next 24 hours he had labile blood pressures fluctuating between extreme hypotension and hypertension. The patient's course was also complicated by acute liver injury and acute renal failure requiring dialysis. 


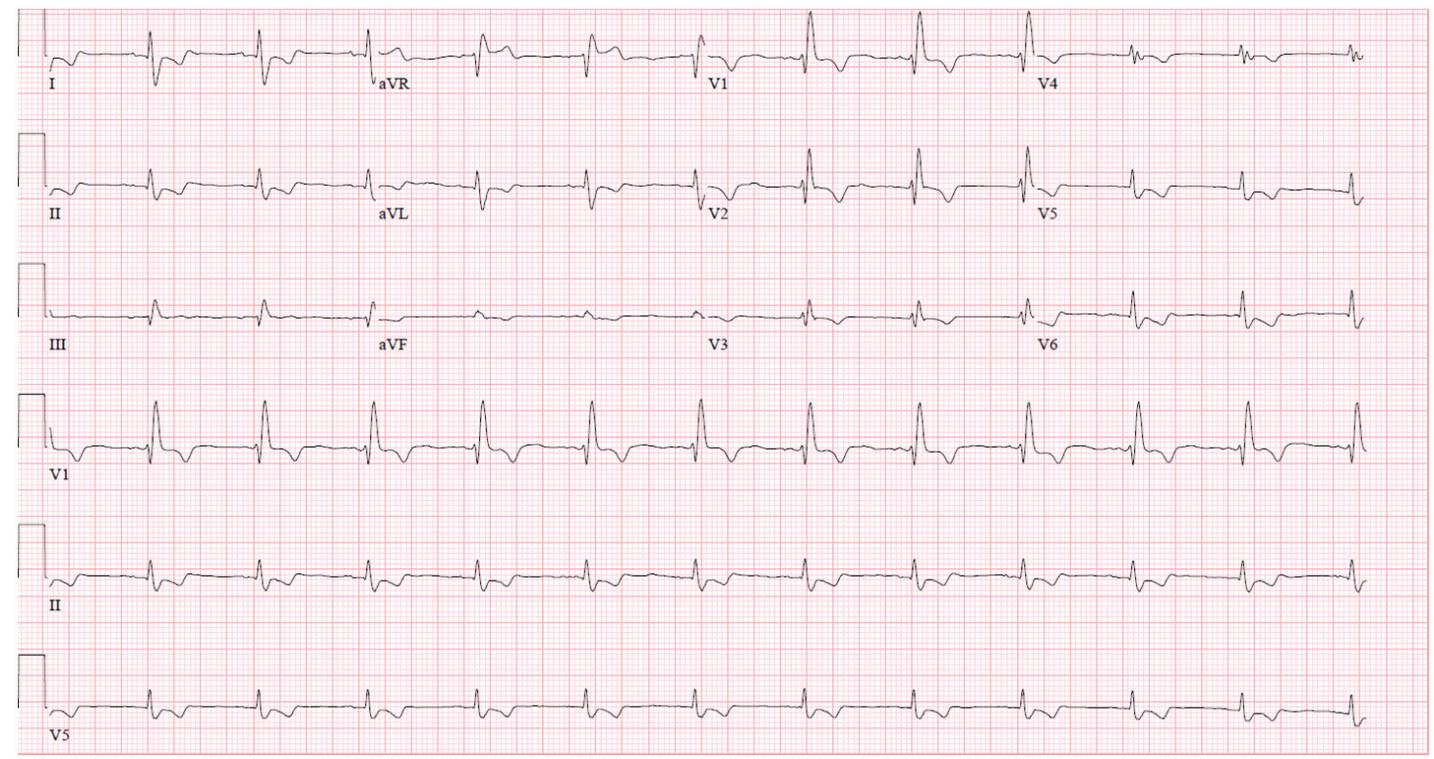

Figure 1. EKG at the time of intubation revealed ST elevations in aVR, ST depressions in I, II, and AVL, and T wave inversions in V1-V6

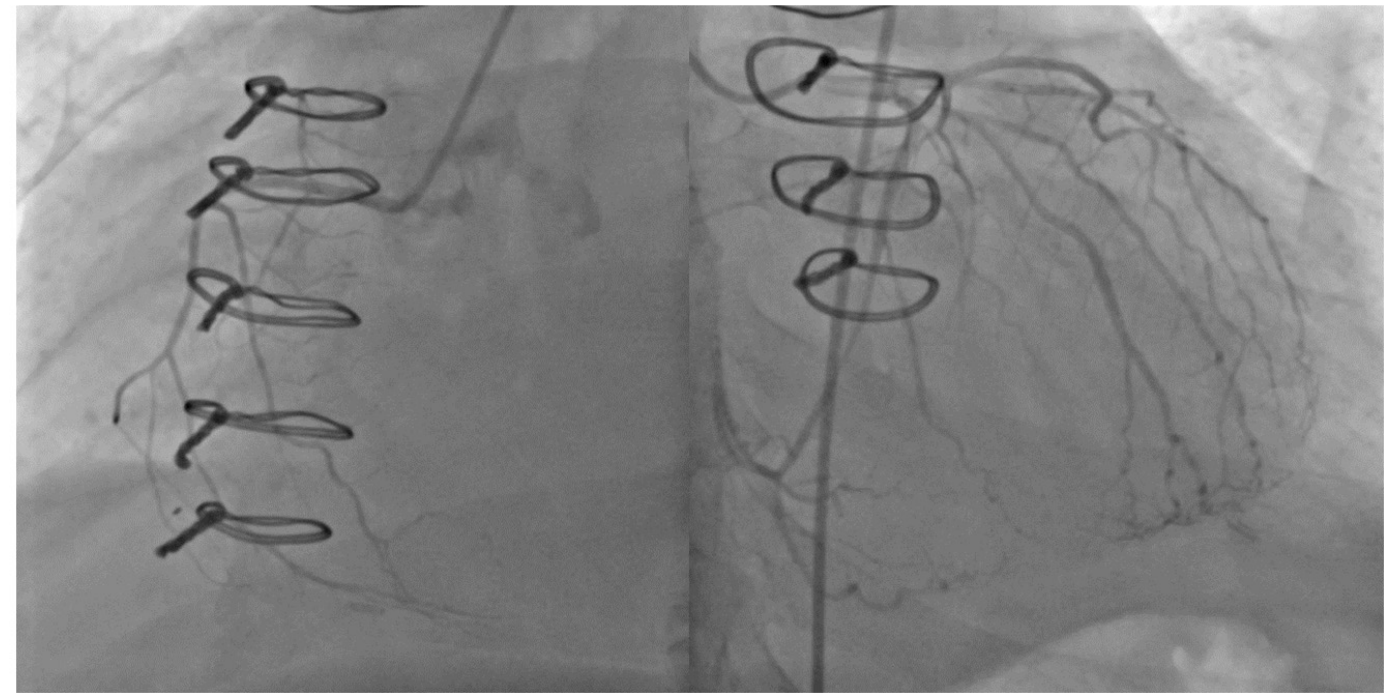

Figure 2. Coronary angiography revealed no obstructive coronary disease

The etiology of his acute decompensation was unclear, however consideration was given to autonomic dysfunction secondary to GBS, acute cellular rejection, and acute myocardial infarction secondary to serum hyperviscosity related to the IVIg infusion. Two days following intubation, empiric treatment of rejection was initiated with pulse dose steroids as no endomyocardial biopsy could safely be obtained at the time. The next day, plasmapheresis was started for further treatment of GBS. Following the second session of plasmapheresis, his mental status, hemodynamics, and end organ function began improving. The patient started producing urine and serum creatinine began to fall, thus prompting cessation of hemodialysis. Likewise, his respiratory strength recovered and he was successfully extubated. The patient's strength improved with repeated sessions of plasmapheresis, though he continued to have paresthesias in his hands and feet. A total of five sessions of plasmapheresis were completed.

The patient was eventually discharged to acute inpatient rehab, where his strength continued to improve and the paresthesias began to resolve over his 25 day stay there. At time of discharge from inpatient rehab, he could walk with a rolling 
walker. Repeat echocardiogram was performed during his rehab stay and revealed recovery of LVEF to $60 \%$. At time of follow up with neurology one year later, his symptoms had resolved.

Table 2. Reported etiologies of GBS in the post-transplant population

\begin{tabular}{ll}
\hline Inciting cause & Number of reports \\
\hline $\mathrm{CMV}^{[5-15]}$ & 18 \\
$\mathrm{EBV}^{[16,17]}$ & 2 \\
$\mathrm{HHV}^{[18]}$ & 1 \\
Coccidioidomycosis $^{[19]}$ & 1 \\
Pneumococcal vaccine $^{[20]}$ & 1 \\
Influenza vaccine $^{[21]}$ & 1 \\
Tacrolimus $^{[3,22]}$ & 2 \\
Cyclosporine $^{[23-25]}$ & 3 \\
C. jejuni $^{[26,27]}$ & 2 \\
\hline
\end{tabular}

Note. $\mathrm{CMV}=$ Cytomegalovirus; $\mathrm{EBV}=$ Ebstein-Barr virus; HHV = Human Herpes virus; C. jejuni $=$ Campylobacter jejuni.

\section{DisCusSion}

GBS is a rare, immune-mediated, progressive polyneuropathy that is associated with significant morbidity and mortality if not recognized and treated in a timely manner. Overall, an individual's lifetime risk of developing GBS is less than $0.1 \%$, and it is slightly more common in men than in women. ${ }^{[1]}$ Classic signs and symptoms include ascending paralysis and areflexia, though the presentation of GBS can have considerable heterogeneity, so a high index of clinical suspicion is often required to make the diagnosis. The most common inciting event in the general population is antecedent infection with C. jejuni, while other infectious etiologies including CMV, Epstein-Barr virus (EBV), influenza A virus, Myocoplasma pneumoniae, hepatitis (A, B and E), Haemophilus influenza, chikungunya virus, Dengue, and most recently Zika have also been described. ${ }^{[1,28-30]}$ While far less common, non-infectious causes of GBS include vaccinations (influenza $\mathrm{A}$, rabies, and pneumococcal conjugate vaccine), medications including calcineurin inhibitors, and more rarely post-surgical and possibly familial causes. $^{[1,3,22-25,31-34]}$ While the presence of immunosuppression is likely protective and responsible for the decreased incidence of GBS following transplantation, a number of cases in this population have been described. Table 2 lists the inciting causes from previous case reports of GBS following transplantation. Not surprisingly the list is similar to that seen in the general population; however, it is notable that relatively few cases have been linked to infection with C. jejuni. Rather, the vast majority of GBS cases following transplantation have been attributed to infection with CMV, which is likely explained by the higher incidence of this opportunistic infection in the transplant population. Other reported causes include infection with EBV, human herpes virus 6 , and coccidioides, while a few case reports have implicated vaccines (pneumococcal and influenza) and calcineurin inhibitors (both tacrolimus and cyclosporine). ${ }^{[3,16-22]}$

Given the prevalence in prior case reports and the temporal relationship of CMV viremia in the present case, we believe our patient most likely developed GBS related to his CMV infection. Table 3 contains a comprehensive list of prior cases of CMV associated GBS following transplantation. Notably, as was the case for our patient, the vast majority of these cases occurred in males with CMV donor-recipient mismatch, and the latency to onset of GBS varied significantly from 5 days to 14 years. The higher incidence in males has also been described in the general population though to a much milder degree, the reason for which is unclear.

While CMV infection is the most likely reason our patient developed GBS, it is important to note there were other possible etiologies. For one, our patient was also found to have norovirus when he was evaluated for worsening diarrhea one month prior to admission for GBS. Shimizu and Tokuda described a case of Miller Fisher syndrome, a GBS variant, induced by norovirus infection. ${ }^{[35]}$ Alternatively, our patient was also receiving tacrolimus for maintenance immunosuppression, which as noted above has also been implicated in the development of GBS. ${ }^{[3,22]}$ While it is not possible to completely rule out norovirus as the inciting factor in our patient, it is unlikely that tacrolimus was the culprit here given that our patient experienced a full and durable recovery despite no change in his maintenance immunosuppression regimen.

The cause of our patient's myocardial infarction and cardiogenic shock was also the topic of considerable debate. The differential diagnosis included acute cellular cardiac allograft rejection, hyperviscosity syndrome, autonomic dysfunction as a result of GBS, and less likely an acute autoimmune or infectious myocarditis. Unfortunately, endomyocardial biopsy could not be obtained due to clinical instability at the time, so he was treated for all of these possibilities, and he subsequently improved.

While IVIg therapy is typically well tolerated, myocardial infarction is a well reported adverse reaction. Stenton et al. described an 81-year old male that developed a non-ST elevation myocardial infarction (NSTEMI) in the setting of IVIg infusion for treatment of toxic epidermal necrolysis. ${ }^{[36]}$ Their review of the literature identified 19 prior case reports in which patients treated with IVIg developed myocardial infarctions. At least one risk factor for coronary artery disease was identified in nearly all of these cases. More recently, Barsheshet et al. described a man diagnosed with GBS that 
developed an ST-elevation myocardial infarction hours after the start of his first IVIg infusion. This patient had significant coronary artery disease and ultimately went on to coronary artery bypass grafting. ${ }^{[4]}$ Agrawal et al. described a 67-year old male being treated for immune thrombocytopenic purpura that suffered an NSTEMI after IVIg infusion. Cardiac catheterization was not obtained; however, he did have a known history of coronary artery disease. ${ }^{[37]}$ Our case differs from these prior descriptions as our patient was status post heart transplantation and had no significant coronary artery disease on coronary angiogram.

Table 3. Prior case reports of CMV induced GBS in transplant recipients

\begin{tabular}{|c|c|c|c|c|c|c|}
\hline Author & Age & Gender & $\begin{array}{l}\text { Transplanted } \\
\text { Organ }\end{array}$ & $\begin{array}{l}\text { CMV } \\
\text { Status } \\
\text { (D/R) }\end{array}$ & $\begin{array}{l}\text { Latency to } \\
\text { GBS }\end{array}$ & $\begin{array}{l}\text { Type and duration of immunosuppression at time of GBS } \\
\text { diagnosis }\end{array}$ \\
\hline $\begin{array}{l}\text { Bale et al. } \\
(1980)^{[5]}\end{array}$ & 42 & M & Kidney & Unknown & 11 months & $\begin{array}{l}\text { Maintenance therapy not specified. Received steroids and } \\
\text { radiotherapy for treatment of acute cellular rejection about one } \\
\text { month post-transplant. }\end{array}$ \\
\hline $\begin{array}{l}\text { Baldwin et al. } \\
(1992)^{[6]}\end{array}$ & 62 & M & Heart & $(+/+)$ & 4.5 months & Cyclosporine, azathioprine, and steroids since time of transplant. \\
\hline $\begin{array}{l}\text { Baldwin et al. } \\
(1992)^{[6]}\end{array}$ & 61 & M & Heart & $(+/-)$ & 4 months & $\begin{array}{l}\text { Cyclosporine, azathioprine, and steroids since time of transplant. } \\
\text { Received additional doses of IV cyclosporine for allograft rejection } \\
\text { two weeks prior to diagnosis of GBS. }\end{array}$ \\
\hline $\begin{array}{l}\text { Lloveras et al. } \\
(1994)^{[8]}\end{array}$ & 48 & M & Kidney & $(+/-)$ & $\sim 6$ months & Maintenance therapy not specified. \\
\hline $\begin{array}{l}\text { Lloveras et al. } \\
(1994)^{[8]}\end{array}$ & 50 & M & Kidney & $(+/-)$ & 2 months & $\begin{array}{l}\text { Maintenance therapy not specified. Had episode of rejection treated } \\
\text { with steroids. }\end{array}$ \\
\hline $\begin{array}{l}\text { De Maar et al. } \\
(1999)^{[7]}\end{array}$ & 58 & M & Kidney & $(+/-)$ & $\sim 4$ months & $\begin{array}{l}\text { Cyclosporine and low dose prednisolone since time of transplant. } \\
\text { Also received treatment of acute cellular rejection } 8 \text { days } \\
\text { post-transplant with methylprednisolone and three doses of } \\
\text { anti-thymocyte globulin. }\end{array}$ \\
\hline $\begin{array}{l}\text { El-Sabrout et al. } \\
(2001)^{[10]}\end{array}$ & 38 & M & Liver & $(+/-)$ & 2 months & $\begin{array}{l}\text { Cyclosporine and prednisone since transplant. Experienced two } \\
\text { episodes of acute cellular rejection, treated with (1) seven days of } \\
\text { OKT3 and (2) tapering steroids. }\end{array}$ \\
\hline $\begin{array}{l}\text { El-Sabrout et al. } \\
(2001)^{[10]}\end{array}$ & 62 & M & Heart & $(+/-)$ & 5 days & OKT3, cyclosporine, prednisone since time of transplant. \\
\hline $\begin{array}{l}\text { El-Sabrout et al. } \\
(2001)^{[10]}\end{array}$ & 30 & M & Liver & $(+/+)$ & 1 year & $\begin{array}{l}\text { Basiliximab induction days 0-4. Cyclosporine, prednisone since } \\
\text { time of transplant. }\end{array}$ \\
\hline $\begin{array}{l}\text { El-Sabrout et al. } \\
(2001)^{[10]}\end{array}$ & 44 & M & Kidney & $(+/-)$ & 2 years & $\begin{array}{l}\text { OKT3 used for treatment of rejection } 2 \text { months post-transplant. } \\
\text { Mycophenolate maintenance therapy used from } 2 \text { months } \\
\text { post-transplant to time of presentation. }\end{array}$ \\
\hline $\begin{array}{l}\text { El-Sabrout et al. } \\
(2001)^{[10]}\end{array}$ & 47 & M & Kidney & Unknown & 7 years & $\begin{array}{l}\text { Maintenance therapy not specified; history of acute cellular } \\
\text { rejection } 7 \text { years prior treated with OKT3. }\end{array}$ \\
\hline $\begin{array}{l}\text { Keithi-Reddy et al. } \\
(2006)^{[9]}\end{array}$ & 48 & M & Kidney & $(-/-)$ & 3 months & $\begin{array}{l}8 \mathrm{mg} / \mathrm{kg} / \text { day cyclosporine; } 750 \mathrm{mg} / \text { day mycophenolate mofetil, } 60 \\
\mathrm{mg} / \text { day prednisolone on tapering schedule since time of transplant. }\end{array}$ \\
\hline $\begin{array}{l}\text { Garcia Alvarez et al. } \\
(2010)^{[11]}\end{array}$ & 22 & $\mathrm{~F}$ & Kidney & $(+/-)$ & 4 weeks & $\begin{array}{l}\text { Steroids, tacrolimus, and mycophenolate mofetil since time of } \\
\text { transplant. }\end{array}$ \\
\hline $\begin{array}{l}\text { Garcia Alvarez et al. } \\
(2010)^{[11]}\end{array}$ & 62 & M & Kidney & Unknown & 2.5 months & $\begin{array}{l}\text { Steroids, tacrolimus, and mycophenolate mofetil since time of } \\
\text { transplant. }\end{array}$ \\
\hline $\begin{array}{l}\text { Papasotiriou et al. } \\
(2012)^{[12]}\end{array}$ & 28 & M & Kidney & $(+/-)$ & 6 months & $\begin{array}{l}\text { Induction of immunosuppression at time of transplant with } \\
\text { basiliximab and methylprednisolone followed by tapering doses of } \\
\text { steroids. Maintenance therapy with tacrolimus and mycophenolate } \\
\text { mofetil ( } 2 \text { g/day) since time of transplant. }\end{array}$ \\
\hline $\begin{array}{l}\text { Hodowanec and } \\
\text { Simon }(2012)^{[15]}\end{array}$ & 44 & M & Heart & Unknown & 14 years & $\begin{array}{l}\text { Maintenance therapy with cyclosporine, mycophenolate mofetil, } \\
\text { and prednisone; duration of this regimen was not specified. } \\
\text { Mycophenolate discontinued two weeks prior to GBS diagnosis due } \\
\text { to diagnosis of CMV colitis. }\end{array}$ \\
\hline $\begin{array}{l}\text { Steger et al. } \\
(2012)^{[13]}\end{array}$ & 40 & M & Heart & $(+/-)$ & 7 months & $\begin{array}{l}\text { Induction immunosuppression with anti-thymocyte globulin, } \\
\text { tapering doses of prednisolone, and azathioprine according to level } \\
\text { of leukocytes. Maintenance therapy with cyclosporine since time of } \\
\text { transplant. }\end{array}$ \\
\hline $\begin{array}{l}\text { Shaban et al. } \\
(2016)^{[14]}\end{array}$ & 62 & $\mathrm{~F}$ & Kidney & $(+/-)$ & 7 months & $\begin{array}{l}\text { Maintenance immunosuppression with tacrolimus and prednisone. } \\
\text { Previously on mycophenolate mofetil, however stopped four } \\
\text { months prior to GBS diagnosis due to oral ulcerations. }\end{array}$ \\
\hline
\end{tabular}

Note. $\mathrm{CMV}$ = Cytomegalovirus; $\mathrm{D}$ = Donor; $\mathrm{R}$ = Recipient; $\mathrm{M}$ = Male; F = Female; $(+)$ = Positive; $(-)$ = Negative; GBS = Guillain-Barré syndrome. 
A study performed by Reinhart and Berchtold examined the in vivo effects of varying concentrations of IVIg therapy on circulation. ${ }^{[38]}$ They found IVIg therapy led to a dosedependent increase in plasma and blood viscosity as well as an increase in erythrocyte aggregation. Furthermore, a retrospective study at Cedars-Sinai Medical Center found that all five of their patients that suffered IVIg associated myocardial infarction had received a preparation with a particularly high osmolality $(1,179 \mathrm{mOsm} / \mathrm{kg}) .{ }^{[39]}$ Our institution uses Gammagard 10\% (Baxter industries), the osmolality of which is $240-300 \mathrm{mOsm} / \mathrm{kg}$, which is similar to physiologic osmolality. The reason why our patient would suffer from apparent hyperviscosity and acute myocardial infarction after receiving this infusion is unclear; however, the temporal relationship between administration of IVIg and development of symptoms makes this a compelling explanation.

Finally, we cannot ignore the possibility our patient suffered from cardiogenic shock as a direct result of GBS. Although the frequency of myocardial involvement is unknown, a number of cardiac pathologies related to GBS have been described. Several explanations for myocardial involvement have been postulated including cross-reactivity of antibodies to lactose-containing gangliosides on the heart as well as increased catecholamine levels and sensitivity. ${ }^{[2]}$

\section{Conclusions}

GBS occurs less frequently in patients following transplantation than in the general population, and the most commonly reported inciting factor in the post-transplant population is infection with CMV. Possible treatment modalities for GBS include plasmapheresis and IVIg infusion. While both are well established methods for treatment of this disorder, IVIg infusion is associated with thrombotic events, and several cases of IVIg associated myocardial infarction have been described, presumably related to increases in serum viscosity that occur as a result of IVIg therapy. Physicians caring for this patient population should be aware of the association between CMV infection and GBS as well as the rare but possible adverse cardiac events associated with IVIg treatment.

\section{CONFLicts OF InTEREST Disclosure}

The authors have declared no conflicts of interest.

\section{REFERENCES}

[1] Willison HJ, Jacobs BC, Van Doorn PA. Guillain-barre syndrome. Lancet. 2016 Aug 13; 388(10045): 717-27. https://doi.org/10 $.1016 / \mathrm{S} 0140-6736(16) 00339-1$

[2] Mukerji S, Aloka F, Farooq MU, et al. Cardiovascular complications of the guillain-barre syndrome. Am J Cardiol. 2009 Nov 15; 104(10): 1452-5. PMid:19892067 https://doi.org/10.1016/j.amjcar d.2009.06.069

[3] Sharma NS, Wille KM, Hoopes CW, et al. Acute demyelinating polyneuropathy after lung transplantation: Guillain-barre syndrome or tacrolimus toxicity? Case Rep Transplant. 2014; 2014: 685010.

[4] Barsheshet A, Marai I, Appel S, et al. Acute ST elevation myocardial infarction during intravenous immunoglobulin infusion Ann N Y Acad Sci. 2007 Sep; 1110: 315-8. PMid:17911446 https://doi.org/10.1196/annals.1423.033

[5] Bale JFJr, Rote NS, Bloomer LC, et al. Guillain-barre-like polyneuropathy after renal transplant: Possible association with cytomegalovirus infection. Arch Neurol. 1980 Dec; 37(12): 784. PMid:6255911 https://doi.org/10.1001/archneur. 198 0.00500610064012

[6] Baldwin RT, Pierce RR, Frazier OH. Guillain-barre syndrome after heart transplantation. J Heart Lung Transplant. 1992 Jul-Aug; 11(4 Pt 1): 817-9. PMid:1323331

[7] De Maar EF, Kas-Deelen DM, de Jager AE, et al. Inflammatory demyelinating polyneuropathy in a kidney transplant patient with cytomegalovirus infection. Nephrol Dial Transplant. 1999 Sep; 14(9): 2228-30. PMid:10489240 https://doi.org/10.1093/ndt/14 .9 .2228

[8] Lloveras JJ, Larrue V, Delisle MB, et al. Guillain-barre syndrome associated with cytomegalovirus infection after kidney transplantation. Presse Med. 1994 Jun 4; 23(21): 976-8. PMid:7937644
[9] Keithi-Reddy SR, Chakravarthi RM, Hussaini SM, et al. Cytomegalovirus disease with guillain-barre syndrome in a cadaver renal allograft recipient: Cause or coincidence. Int Urol Nephrol. 2007; 39(3): 967-70. PMid:17450421 https ://doi .org/10.100 7/s11255-007-9197-7

[10] El-Sabrout RA, Radovancevic B, Ankoma-Sey V, et al. Guillainbarre syndrome after solid organ transplantation. Transplantation. 2001 May 15; 71(9): 1311-6. PMid:11397969 https://doi.org/ 10.1097/00007890-200105150-00023

[11] Garcia Alvarez T, Garcia Herrera A, Mazuecos Blanca A, et al. Guillain-barre syndrome in kidney transplant. Nefrologia. 2010; 30(2): 260-1. PMid:20393626

[12] Papasotiriou M, Papachristou E, Marangos M, et al. Cytomegalovirus polyradiculopathy of late onset in a young renal transplant recipient. Clin Nephrol. 2013 Jul; 80(1): 75-8. PMid:23803598 https: //doi.org/10.5414/CN107479

[13] Steger CM, Antretter H, Hofer D. Guillain-barre syndrome due to CMV reactivation after cardiac transplantation. Case Rep Cardiol. 2012; 2012: 506290. https://doi.org/10.1155/2012/506290

[14] Shaban E, Gohh R, Knoll BM. Late-onset cytomegalovirus infection complicated by guillain-barre syndrome in a kidney transplant recipient: Case report and review of the literature. Infection. $2016 \mathrm{Apr}$; 44(2): 255-8. PMid:26141820 https://doi.org/10.1007/s150 10-015-0819-1

[15] Hodowanec AC, Simon DM. Late primary cytomegalovirus infection presenting with acute inflammatory demyelinating polyneuropathy in a heart transplant recipient: A case report and review of the literature. Transpl Infect Dis. 2012 Oct; 14(5): E116-20. PMid:22938143 https://doi.org/10.1111/tid.12000

[16] Masajtis-Zagajewska A, Muras K, Mochecka-Thoelke A, et al. Guillain-barre syndrome in the course of EBV infection after kidney transplantation-a case report. Ann Transplant. 2012 Jul-Sep; 
17(3): 133-7. PMid:23018266 https ://doi.org/10.12659/AOT .883468

[17] Ostronoff F, Perales MA, Stubblefield MD, et al. Rituximabresponsive guillain-barre syndrome following allogeneic hematopoietic SCT. Bone Marrow Transplant. 2008 Jul; 42(1): 71-2. PMid:18391992 https://doi .org/10.1038/bmt.2008.81

[18] Tomaszewska A, Nasilowska-Adamska B, Dzieciatkowski T, et al. Simultaneous human herpesvirus 6-associated encephalitis and guillain-barre syndrome in a patient after matched unrelated donor haematopoietic stem cell transplantation. Arch Med Sci. 2010 Apr 30; 6(2): 288-90. PMid:22371761 https://doi.org/10.5114/ aoms . 2010.13912

[19] Murali HR, Josephs KA, Wijdicks EF. Guillain-barre syndrome in an immunocompromised patient and coccidioidomycosis infection. Rev Neurol Dis. 2006 Spring; 3(2): 82-4. PMid:16819425

[20] Cordonnier C, Ljungman P, Juergens C, et al. Immunogenicity, safety, and tolerability of 13-valent pneumococcal conjugate vaccine followed by 23 -valent pneumococcal polysaccharide vaccine in recipients of allogeneic hematopoietic stem cell transplant aged $>/=2$ years: An open-label study. Clin Infect Dis. 2015 Aug 1; 61(3): 313-23. PMid:25870329 https://doi.org/10.1093/cid/civ287

[21] Moon JS, Souayah N. Guillain-barre syndrome triggered by influenza vaccination in a recipient of liver transplant on FK506. Liver Transpl. 2006 Oct; 12(10): 1537-9. PMid:17004261 https : //doi.org/10.1002/lt. 20864

[22] Jakes AD, Jani P, Bhandari S. Case report: Guillain-barre syndrome following renal transplantation-a diagnostic dilemma. Nephron Clin Pract. 2013; 124(3-4): 239-42. PMid:24503667 https : //doi .or $\mathrm{g} / 10.1159 / 000358087$

[23] Terrovitis IV, Nanas SN, Rombos AK, et al. Reversible symmetric polyneuropathy with paraplegia after heart transplantation. Transplantation. 1998 May 27; 65(10): 1394-5. PMid:9625024 https: //doi.org/10.1097/00007890-199805270-00018

[24] Palmer BF, Toto RD. Severe neurologic toxicity induced by cyclosporine A in three renal transplant patients. Am J Kidney Dis. 1991 Jul; 18(1): 116-21. https://doi.org/10.1016/S0272-6 386(12) 80300-3

[25] Falk JA, Cordova FC, Popescu A, et al. Treatment of guillain-barre syndrome induced by cyclosporine in a lung transplant patient. $\mathrm{J}$ Heart Lung Transplant. 2006 Jan; 25(1): 140-3. PMid:16399546 https://doi.org/10.1016/j.healun.2005.06.012

[26] Colle I, Van Vlierberghe H, Troisi R, et al. Campylobacter-associated guillain-barre syndrome after orthotopic liver transplantation for hepatitis C cirrhosis: A case report. Hepatol Res. 2002 Oct; 24(2): 205. https://doi.org/10.1016/S1386-6346(02)00084-0

[27] Maccario M, Tarantino A, Nobile-Orazio E, et al. Campylobacter jejuni bacteremia and guillain-barre syndrome in a renal transplant recipient. Transpl Int. 1998; 11(6): 439-42. PMid:9870273
[28] Wijdicks EF, Klein CJ. Guillain-barre syndrome. Mayo Clin Proc. 2017 Mar; 92(3): 467-79. PMid:28259232 https ://doi .org/10 $.1016 / j$.mayocp. 2016.12.002

[29] Dos Santos T, Rodriguez A, Almiron M, et al. Zika virus and the guillain-barre syndrome - case series from seven countries. N Engl J Med. 2016 Oct 20; 375(16): 1598-601. PMid:27579558 https://doi.org/10.1056/NEJMc1609015

[30] Song BH, Yun SI, Woolley M, et al. Zika virus: History, epidemiology, transmission, and clinical presentation. J Neuroimmunol. 2017 https://doi.org/10.1016/j.jneuroim.2017.03.001

[31] Salmon DA, Proschan M, Forshee R, et al. Association between guillain-barre syndrome and influenza A (H1N1) 2009 monovalent inactivated vaccines in the USA: A meta-analysis. Lancet. $2013 \mathrm{Apr}$ 27; 381(9876): 1461-8. https ://doi.org/10.1016/S0140-673 6(12) 62189-8

[32] Moro PL, Woo EJ, Paul W, et al. Post-marketing surveillance of human rabies diploid cell vaccine (imovax) in the vaccine adverse event reporting system (VAERS) in the united states, 19902015. PLoS Negl Trop Dis. 2016 Jul 13; 10(7): e0004846. PMid:27410239 https://doi.org/10.1371/journal.pntd.0004846

[33] Cicciu M, Herford AS, Bramanti E, et al. Guillain-barre syndrome: Report of two rare clinical cases occurring after allergenic bone grafting in oral maxillofacial surgery. Int J Clin Exp Pathol. 2015 Jun 1; 8(6): 7614-6. PMid:26261679

[34] Geleijns K, Brouwer BA, Jacobs BC, et al. The occurrence of guillainbarre syndrome within families. Neurology. 2004 Nov 9; 63(9): 1747 50. PMid:15534275 https: //doi .org/10.1212/01. WNL. 00001 43055.09646 .31

[35] Shimizu T, Tokuda Y. Miller fisher syndrome linked to norovirus infection. BMJ Case Rep. 2012 Dec 14; 2012: 10.1136/bcr, 2012007776.

[36] Stenton SB, Dalen D, Wilbur K. Myocardial infarction associated with intravenous immune globulin. Ann Pharmacother. 2005 Dec; 39(12): 2114-8. PMid:16288078 https : //doi .org/10.1345/ap h. $1 \mathrm{G} 104$

[37] Agrawal Y, Jacob C, Demchuk N, et al. Immune modulatory therapy causing acute coronary syndrome. Am J Ther. 2015. PMid:26720165 https://doi.org/10.1097/MJT.0000000000000373

[38] Reinhart WH, Berchtold PE. Effect of high-dose intravenous immunoglobulin therapy on blood rheology. Lancet. 1992 Mar 14; 339(8794): 662-4. https://doi.org/10.1016/0140-6736(92 ) $90806-E$

[39] Vo AA, Cam V, Toyoda M, et al. Safety and adverse events profiles of intravenous gammaglobulin products used for immunomodulation: A single-center experience. Clin J Am Soc Nephrol. 2006 Jul; 1(4): 844-52. PMid:17699296 https ://doi .org/10.2215/CJN. 0170 1105 